\title{
RURAL AND REGIONAL DEVELOPMENT POLICIES IN EUROPE: SOCIAL FARMING IN THE COMMON STRATEGIC FRAMEWORK (HORIZON 2020)
}

\author{
Antoni Francesc TULLA, Ana VERA, Anna BADIA, Carles GUIRADO, \\ Natàlia VALLDEPERAS \\ Department of Geography, Universitat Autònoma de Barcelona, Catalonia, Spain
}

\begin{abstract}
Social Farming (SF) is an emerging sector in the rural European context, but the European Economic and Social Committee (2013/C 44/07) emphasizes that SF should be planned and implemented under the new 2014-20 rural development policy because of the positive results obtained. The SF concept can be associated with agriculture as a multifunctional activity, giving agricultural practice new meanings and functions and incorporating social services, medical treatment and rehabilitation, and educational training and support. In addition, agriculture must be considered as a means of employment and social integration for groups as diverse as individuals who are unemployed or living with mental retardation, mental disorders, or addictions, among others. As a result, innovative SF activities are contributing to the social economy, rural and regional development, and support for a new agro-social paradigm. These are mainly activities linked with the endogenous resources of the territory that generate new enterprises, together with complementary activities that consolidate an economic network as the basis for regional development.
\end{abstract}

Key Words: social farming, regional development, European structural funds, rural areas, Catalonia.

\section{Introduction}

This article aims to show that Social Farming (SF) is an activity that can support sustainable regional development and alleviate the growing inequalities between rural and urban areas. Regional development has often been based on urban systems because industries and services replaced agrarian activities as the economic engine of the $20^{\text {th }}$ century. The core-periphery model shows that areas where agrarian activity predominates have a survival economy while urban areas modernize, giving way to a dual economy (Lipton 1977) that leads to uneven regional development. This is due to an imbalance in the distribution of power, not only to the resources available in the territory (Wallerstein 1979). Economic development can be defined as the modification of human and natural factors to produce growth in a particular area of specific economic variables, such as productivity or Gross National Product (GNP). However, this requires political willpower in territorial planning and regulations that protect and promote less economically dynamic areas.

The value that is currently placed on the natural environment and quality of life of a population requires that we work towards sustainable development involving alternatives that take into account the renewal capacity of an area's natural and human resources (Pearce 1976). Regional development requires an economic balance between the various areas of a country; otherwise, excessive movements of human and material resources can preclude a minimum level of sustainability or quality of life in some territories (Tălângă et al. 2011). In this scenario, 
supportive measures are most needed in rural areas, where local development can be due to endogenous or exogenous factors. The former may include the arrival on the economic and social scene of innovative individuals whose activities produce gains that can be reinvested in the same area. The most important exogenous factors are derived from advantages in transportation, communications, and other facilities that, together with external investments, allow the creation or renewal of economically competitive activities. The key element in regional development is the continuous growth in technological innovation, which implies greater capital needs and may bring with it dependency on external investors or taking advantage of the territory itself for tourism or value-added agrarian activities (Tulla et al. 2009).

In the western nations, rural spaces are undergoing profound changes. Shaping a new postindustrial society (Bell 1999), in which the industrial sector is no longer dominant, leads to the expansion of services and the disappearance of the fordist division of labour. In this new scenario, new information technologies occupy a prominent position, and they develop in parallel fashion, with less differentiation between rural and urban spaces (Pahl 1966, Sempere and Tulla 2008). The industrialization of agriculture after the Second World War, which some authors have called the "Green Revolution" (Lockwood 1999), brought major changes to the productive function of rural areas, converting traditional production to competitive products adapted to market demands. The mechanization of fieldwork and need for increasingly large extensions of land brought about a significant decline in workforce, the disappearance of many small farms, and finally, a major reduction in agrarian sector employment (Van der Ploeg 2006). This restructuring caused the commodification of the countryside - a shift from landscapes of production to landscapes of consumption, in the words of Cloke (2006). The agrarian productive function has given way to tourism and counterurbanization as tools for structuring rural areas, even with respect to social and territorial organization (Clout 1972, Woods 2005).

In the capitalist concept of agriculture, nature has a subsidiary role and there are major environmental impacts due to intensive use of the territory, excessive pressure on natural resources, and the use of chemicals and genetic modifications that have damaging effects on human health. This tendency worsens with the promotion of monocultures instead of multicrop diversity, land erosion when fields and traditional land management methods are abandoned, especially in the mountain areas (Barrachina and Tulla 2010), and other factors. In the 1980s, organized efforts began to implement rural multifunctionality as a process of integration with rural development efforts, where agrarian activity is considered economically residual (Armesto 2005). These initiatives emphasize rural tourism, ecotourism or adventure sports, complemented by cultural values related to natural or monumental heritage and the artisan activities related to a specific territory (food products) or new settlers (textile and other artists).

Agrarian activity is considered an opportunity to construct alternative economic models not based exclusively on tourism. This new concept has produced a change in the role of farms and farmers in modern society, giving rise to a new farm culture, with a new consciousness, new values and new means of production, as studied by Neus Monllor (2011) in Catalonia and Ontario (Canada). The emerging farmer has a series of new values, including ecological "farmto-table" production ${ }^{1)}$ using local and sometimes heritage varietals, and responds to the new expectations of certain consumer groups that look for food products with characteristics related to a healthier lifestyle with environmental awareness and social responsibility (Carbone and Senni 2010). In this context, the SF appears to offer a new activity that can, of itself, assist in

1) Also named "farm-to-fork" or "proximity agriculture". It's a new trend of local farms selling products in their surrounding area. There is a new group of restaurants, called "kilometer zero" or "slow food", which uses a percentage of products from less than a hundred kilometers distance. 
local development and, if networks of cooperation are established between the various advocates, at the regional level as well. In Catalonia, there are diverse networks that help with product distribution, support entrepreneurs, and provide training and advice in the search for financing, among other things. The most important of these is the Social Farm Network (Xarxa CX Agrosocial 2011), a group of 15 enterprises providing more than 1400 jobs, 1100 of them filled by people with a disability or at risk of social exclusion.

Regional development refers to funding policies and internal or external actions taken to improve areas in need of economic development (Foster and Sen 1997). This often means a combination of regional and agricultural sector policies. In the European Union (EU), the Common Agricultural Policy (CAP) includes SF in the Common Strategic Framework (Willems 2013). The idea is that SF can add value by affecting not only agrarian activity but also health care, services, the environment, research and employment. This is why EU governments, and therefore common EU policy, must promote activities that support and promote SF. In recent years, this has included EU grants based on economic diversification policies, social inclusion, and rural development, such as the Leader programmes, to encourage these activities. If SF is recognized as an important element of rural economic development in the next Horizon 2020 framework as programmed (2014-2020), this should provide access to new funding sources and an opportunity to present proposals for European Structural Funds (EAFRD, ESF and ERDF $)^{2)}$.

Without a doubt, SF could become a key element in the regional development of many rural areas of Europe. Therefore, it seems important to analyze the possibilities for SF development, taking as our guide the European SoFar network (2005 and 2008) and the specific experience in Catalonia (Xarxa CX Agrosocial 2011).

\section{Methodology}

This study applied two scales of analysis, the first being a general overview of the context for the SF concept and the European examples and the second one is a more local analysis of the experience to date in Catalonia (Fig. 1). The methodology was three-pronged: a literature review, including websites; in-depth interviews and survey research; and analysis of statistical data. In broad strokes, the structure of the bibliographic research was as follows: the transformation of agriculture and rural areas in the past 30 years, the application of regional and local development policies, and SF and a new social and economic environment that combines health and cultural services with activities that help to provide employment and social integration for at-risk groups.

In Catalonia, 105 entities were identified and can be considered SF because the workers who benefit have a disability or belong to at-risk groups. Garden stores constitute about $50 \%$ of these entities, and a process of diversification or changes in activity were observed; the other $50 \%$ are related to farming, greenhouses, forestry, lumbering, vineyards, olive groves, the production of wine and olive oil, cattle, the food industry (primarily dairy and beef production) or other farm products. There are two areas of specialization that, like the garden stores, have their own particular dynamics: environmental education and catering or restaurant food preparation. The statistical sources used to calculate the presence of groups with disabilities or at risk of social exclusion were from the Catalan Statistical Institute (IDESCAT 2013) and union groups (UGT 2012).

2) EAFRD (European Actions for Rural Development), ESF (European Social Fund), and ERDF (European Rural Development Fund). 


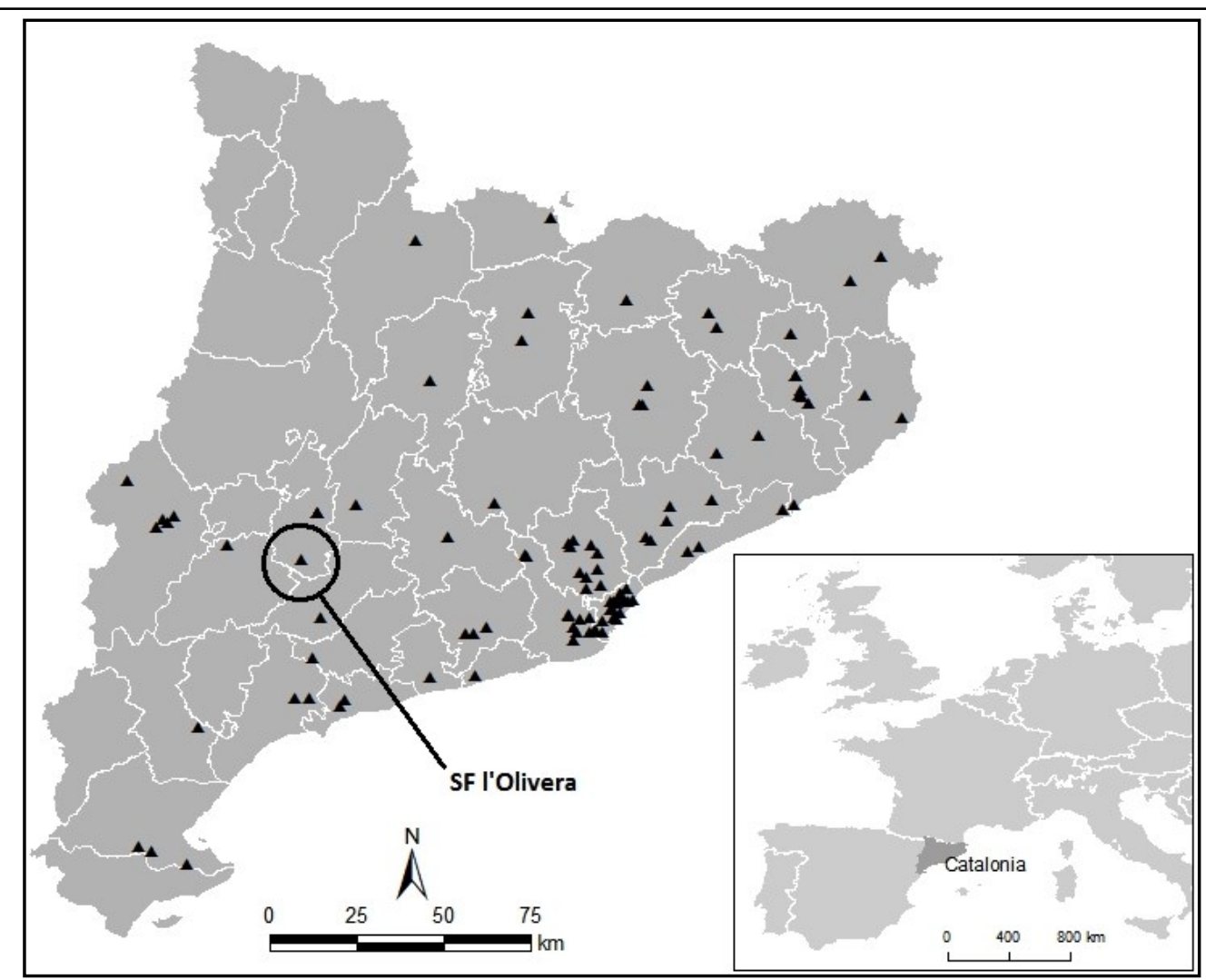

Fig. 1 - Localization of SF in Catalonia Source: RecerCaixa 2011 ACUP023

In-depth interviews and surveys provided a picture of the SF activity in Catalonia. The 22 interviews were conducted with two types of individuals: (a) advocates of a particular entity who were members of a foundation that supported it or of an administrative council for a nonprofit business; and (b) key informants responsible for particular networks. In addition, 65 questionnaires were administered. The interviews were intended to reveal the characteristics and operations of the SF entities and the 25 survey questions requested basic information about the entities' work. In Catalonia, approximately $25 \%$ of the staff and advocates are women; therefore, we explored the gender balance in other European countries (Berenguer 2013): the proportion is similar in The Netherlands (Bock 2004) and it exceeds 60\% in Italy (Di lacovo 2003). However, $50 \%$ of the population served in Catalonia is female (IDESCAT 2013, UGT 2012).

Basically, we were interested in determining the environments in which SF can develop, based on the agents involved, the type of activities and the profile of those who benefit. It is necessary to know the legal framework related to the inclusion of individuals with a disability in employment and social engagement, because it affects the possibilities for expanding the SF activity.

3) The TSS consists of legally recognized organizations inscribed in the public register as nonprofits, i.e., which reinvest their benefits in their own activity and which are private rather than public (Anuari TSS a Catalunya 2009). The social cooperatives in Italy can also be considered TSS. 
In Catalonia, the third social sector (TSS ${ }^{3)}$ is very important and, under the Spanish law that requires hiring workers with a disability (LISMI) and the Catalan legislation ${ }^{4}$, SF is compatible with legal entities such as Special Employment Centres (SEC). The SEC has a variety of legal options for business status, from a cooperative to an anonymous society, but it must register as a business ${ }^{5}$. The main requirement to be considered a SEC is that at least $70 \%$ of the workforce under standard contract must have a disability or be a member of an at-risk group. The subsidy for investments and to support labour costs can reach $50 \%$ if the entity offers a service plan that includes rehabilitation, therapy, and social, cultural and sport integration.

The body of information obtained from the literature search, interviews and surveys provided sufficient knowledge to describe the SF experience in Europe in general and in Catalonia in particular. The most difficult part, because this activity is relatively new, was to determine the links between regional and local development policies and the SF experiences. In this sense, the study of networks such as SoFar (2005 and 2008) and COST Action 866 (2006-2010) in Europe, CX AgroSocial (2011) in Catalonia, or Réseau Cocagne (2007) and Réseau Astra (2009) in France have been more important. The creation of networks strengthens the relationship between SF objectives and regional development because they help to better determine the needs of each place and population.

\section{A general overview on Social Farming}

There are three potential areas of SF contribution to regional development policy: (1) the need to deliver services to population groups at risk of social marginality (Di lacovo and O'Connor 2009); (2) the new strategies for rural entrepreneurship that seek out new activities of interest to a certain segment of society and generate income (O'Connor et al. 2010); and (3) the new Common Agricultural Policy (CAP), which considers rural development to be important ${ }^{6)}$, increasing environmental action through programmes such as the green checque "greening" (Katsarova 2013). This last relationship will be strengthened by the measures proposed in the Common Strategic Framework (Willems 2013). It is evident that SF, even in its early phase as a strategic development tool, can be beneficial for rural areas. First of all, we must understand SF and the process that has been followed to date.

Social Farming consists of a broad range of activities that have certain things in common: farm production and direct services to empower groups of individuals, such as people with a physical or mental disability; people seeking recovery from drug addiction, imprisonment, or failure in school; the elderly; abused women; and at present, the unemployed and farms that are failing (Di lacovo 2011, Guirado et al. 2013b). In other European countries, numerous models exist that combine voluntary and public social services initiatives, public and private funding, and regulations concerning employment, social outreach and economic support for at-risk groups and individuals (Di lacovo 2010), as we discuss below.

With the creation of the SoFar network (2005-08) and the attention received from the EU (Willems 2013), SF has achieved greater recognition. Although the traditional concept had been the more restrictive "Green care", SF is now becoming more generalized and it includes different lenses. Green care was limited to activities and practices unified by the idea of using nature to improve mental and physical human health, albeit in a variety of different ways.

4) Special Employment Centers are qualified by the Catalan government, the Generalitat de Catalunya (Centres Especials de Treball de Catalunya, 2012) Under the April 7, 1982, Spanish Law on social integration of people with disabilities (LISMI, Ley 13/1982).

5) Registre d'Entitats, Serveis i Establiments Socials (RESES).

6) This concerns the second pillar of the CAP, with the $25 \%$ of the budget. 
Sempik et al. (2010) grouped these activities into two large categories: on one hand, experiencing the natural environment through the senses ("looking at nature") or outdoor physical activity ("being active in nature"), a category that encompasses curative and therapeutic properties; on the other hand, working in the natural environment ("shaping nature") includes planting, gardening, or therapies involving interaction with the animal world.

Another concept is "Care farming", which uses commercial farming and the agricultural landscape as the basis for promoting physical and mental health, establishing a cooperative triangle involving farmers, health and human services professionals, and care receivers (Hine et al. 2008). Another related concept, "Farming for health", refers to the combination of agricultural labour and care for individuals that emphasizes both the agricultural sector (including farming and the social environment) and the health and human services system of institutions, care providers and care receivers (Dessein 2008).

In contrast to these other concepts, SF always takes into consideration the social and territorial context, seeking diversification of economic activity, better access to services, and improved quality of life for all inhabitants of the territory (Di lacovo and O'Connor 2009). The SF territorial framework becomes a useful instrument for local and regional development, as the European Economic and Social Committee (Willems 2013) has recognized in the current framework programme (2014-2020).

At present, SF can be considered an agrarian or generically rural activity with two major vectors: impact on a broad range of at-risk groups and the capacity to generate economic activities that contribute to local and regional progress. There are six basic areas of SF activity that cover the diverse experiences to date in European countries (SoFar 2005, 2008; COST Action 866 2006-10, Guirado et al. 2013b):

- Therapy, including activities involving horticulture and animal care that benefit individuals with a mental disability, disease or disorder, with special education needs, etc. Rehabilitation takes place in residential treatment facilities and penitentiary centres, treating persons with alcohol and/or drug addiction, traumatic experiences (physical or mental abuse, rape), or recovering from illness, as well as problem youth and those with eating disorders, treated in centres for minors.

- Workforce readiness prepares individuals with physical and/or mental disability to participate in the production and distribution cycle, to the best of their abilities. It also includes training in new marketable skills for those being released from penitentiary centres, young people who failed in school, and others needing to enter the workforce. We must highlight that professional training is provided for groups that had no previous opportunity to learn or who left school. Since the services are for groups that are disadvantaged in obtaining employment, the public administration provides certain subsidies.

Inclusion in mainstream schools of students with various problems requires activities that facilitate learning in general and job skills or the trades in particular. Many of these students have special needs or adjustment problems. These training activities are based in learning about farm life and production cycles (farm-school, school garden plots, etc.). There are also cultural activities that reassess and communicate rural values and customs as part of the social integration of at-risk groups. 
- Work with individuals and groups at high risk of social exclusion (due to homelessness, immigration, abuse, unemployment, age [children and the elderly], etc.) to facilitate their inclusion, which can empower these groups. Social cohesion is the goal of community projects that engage different social groups to benefit interpersonal relationships (community gardens, consumer cooperatives, etc.).

- $\quad$ Promotion of small farms and artisans (not particularly viable in a competitive economy), by means of organic production, diversification and a commitment to groups at risk of social exclusion. The intersection of two problematic situations (farmers at economic risk and groups at social risk), together with structural assistance policies of the CAP and other institutions, can lead to a rural recovery that will help to shape regional development.

- $\quad$ Social-recreation activities with the objective of improving quality of life and personal or social engagement, directed at persons with special needs (people with disabilities, children, families, the elderly). Examples are socially conscious agrotourism or educational activities on farms, whether paid for by the participants or partially subsidized by private or public entities.

The types of SF economic activities can be classified using two criteria (Di lacovo and O'Connor 2009): the uses made of nature and the degree of personnel specialization. Types of use range from primarily therapeutic $(T)$ to the production $(P)$ of foods or artisanal items. Types of personnel training range from health professions (HP) to the agrarian sector (AS), related to rural transformation or tourism.

When we cross these criteria (2X2 matrix), the classification generates four broad groups of activities:

1) Treatment units in hospitals and specialized centres that use contact with nature as part of a cure. Personnel have more training in health care than in economics. The care provided in this environment is very formal. These centres may be part of the public health system or private foundations $(T-H P)$.

2) Social economy projects, with the objective of producing foods or artisanal craft items, taking into account the therapeutic functions that can improve the social participation of individuals with physical or mental disabilities. Personnel have training in both health-related and economic fields. The entities that take on these projects are nonprofit organizations or "social entrepreneurship" businesses that receive public or private funding (T - AS).

3) Farms specializing in health and human services. The primary function is agricultural production, with personnel who are farmers but also take therapeutic and health-related aspects into account. There may be personnel with some type of health-care training, but the centres provide an informal environment. The priority is not to achieve economic profit; family members and charities often provide private subsidy for the operation. The main objective is better health through agrarian activity $(P-H P)$.

4) Inclusive farming sites, where the activity is agrarian or rural tourism. Within a framework of publicly or privately funded structured programs, employees are drawn from groups at risk of social exclusion. Personnel have training in farming and/or rural tourism. The operations seek economic benefit, often achieved by public subsidy or private contributions from foundations or 
family members of the employees from at-risk groups (P - AS).

At the larger scale, the initial results of the bibliographic analysis showed that the majority of the studies have been done at the beginning of the $21^{\text {st }}$ century, although some European studies are available from the latter decades of the $20^{\text {th }}$ century. The experience in Catalonia is more recent and there is not much documentation from which to study them.

The judicial and financial system related to SF varies by country. In Italy, one of the pioneers, where SF began in the 1970s, we found three general types: nonprofit organizations, such as social cooperatives; private initiatives that attempt to make a profit, and volunteer organizations that actively support public or private initiatives. The situation is similar in Catalonia. However, SF could be considered a mature concept in Italy, where there were 6000 social cooperatives and 190,000 employees in 2003 (Istat 2006), but in 2011 there were only a hundred entities and 3,000 employees in Catalonia (Fig. 1) (Xarxa CX Agrosocial 2011). Our research identified only 5 sites in the rest of Spain.

In Europe, SF has adapted to the diverse public approaches to health services, to the harms caused by unemployment, to the policies on social integration about at-risk groups and, very importantly, to the capacity for initiative among the advocates for public or private entities with an interest in resolving the issues. The different models take into account at least the following five elements: 1) the systems that regulate health and human services, 2) the society's state of well-being, 3) funding, 4) the typology of the actors, and finally, 5) how SF is managed. These five elements and the unique composition of each territory have given way to very different systems of SF organization. In Europe, four major models have been described (Esping 1995, Haugan et al. 2006, SoFar 2005, 2008, Guirado et al. 2013b):

- $\quad$ Social democrat. In northern Europe (Denmark, Finland, Norway, Sweden), this model is based on the fundamental right of all citizens to access health and social services through a national health system, and it is sustained by high taxes on the inhabitants. These services have been decentralized, and more than $60 \%$ are offered by a city or county, which guarantees ongoing training for those who participate in the farm projects. Instead of creating specific institutions, the farms are subsidized when the owner acts as a supervisor, taking responsibility for a few at-risk individuals. Therefore, there is a dual objective: policies of social integration and policies that provide economic support for the farms.

- Corporate. This model exists in central Europe (Germany, Austria, Belgium, France, The Netherlands, and Luxemburg). It also guarantees everyone's access to public health services by paying into the social security system, but it allows the establishment of private systems that act in parallel with the public system and they can become providers of health and social services under public contract. There is a public interest in promoting "care farms" and, thanks to the subsidization policies, many training courses are organized. As a result, SF is considered by the concerned stakeholders as an action of solidarity rather than as a profitable business. Nonetheless, there is high pressure from funding agencies to increase the production of food or services, to be more self-sufficient and less dependent upon public subsidies.

- $\quad($ Neo)Liberal. Primarily present in Ireland and the United Kingdom, this model is based mainly on assistance to families and individuals with specific needs and difficulties, provided through the TSS (associations, foundations, etc.), volunteers, and public or church-related charities work. The public system does not guarantee universal 
coverage. Access to health care depends in large part on private insurance contracts. The actors are outside of public institutions and the management is the responsibility of civil society with private or foundation funding, or partial support from the public sector.

- Mixed. This model, present in Mediterranean countries (Italy, Spain), is a combination of the social democratic and corporate models: the private and public sectors coexist as service providers. At the same time, the TSS is especially valuable in this model, working directly with families to care for individuals. In this case, we find ourselves with a fragmented system, in which the existence of a public health system, increasingly weakened, is complemented by a private system that is expanding because of government policies. The strong presence of the TSS means that some services are no longer offered by the public system; they are delegated to nonprofit organizations. At the same time, families have an active role in promoting many of these nonprofit service providers that provide individualized support depending on the framework of SF activities.

The abyss that has been created between the needs in the population and the state's capacity to provide services was evident during the periods of economic growth at the end of the $20^{\text {th }}$ century, but it is even more noticeable in the current crisis. In many countries, the tradition of associations has spontaneously generated new types of organization of the civil society ${ }^{7}$ and bottom-up social practices. It is often easier in agricultural and rural areas to incorporate workers with various kinds of disabilities or at risk of social marginalization. Many initiatives have sprung from the traditions of solidarity and volunteerism, whether of religious origin or community-based or from some other mutual-benefit organization. Without a doubt, the fabric of each country affects the implementation of SF-oriented entities.

One of the most remarkable changes in Europe over the past 25 years has been legal reform that transformed the traditional welfare state from a public system to a mixed public-private system. The most extreme examples in Italy and Catalonia are social cooperatives and not-forprofit enterprises, both of which are in the TSS (SoFar 2005, 2008, Guirado et al. 2013b). Interest in strengthening SF in some countries must also be associated with new opportunities in multifunctional agriculture to contribute to rural development (Van der Ploeg 2006). In a wider sense, rurality includes both existing farm operations and those that are created as part of urban migration to the countryside (Woods 2005). What must be noted in both cases is the orientation towards projects that favour the rehabilitation and workplace integration of people with special needs. The first efforts were more focused on individuals with physical or mental disability, but over time this has become generalized to include all at-risk groups. Altogether, the diverse initiatives that have strengthened SF have helped to consolidate regional development policies, especially when networks are created between SF entities that also reinforce the structure of available services in a particular area.

\section{Regional development and local rural projects in Catalonia}

Social Farming projects provide a strong boost to economic and social development at the local level. In rural areas, activities linked to the territory and products from the land have greater repercussion for endogenous development, social cohesion and the fabric of the business environment (Tulla et al. 2009). These are more socially responsible initiatives and also more

7) Civil society, in contrast to the TSS, does not necessarily require legal recognition of the entity, and can embrace very diverse organizational structures (neighborhood associations, church groups, nongovernmental organizations, etc.). 
respectful of the land and environment, strengthening the values that make positive contributions to the construction of new models of development. There is a reassessment of agrarian activities and of the new multifunctional pattern in rural areas. At the same time, resources from the local territory of each SF installation are more valued, generating both new and older forms of economically productive activity and helping to achieve social gains through their services, facilities, and infrastructure. We could say, then, that these initiatives help to energize rural areas, generating new places of employment that help to stabilize the population with a more attractive level of services and reinforcing the networks of small cities in the countryside (Zamfir et al. 2009). Apart from the specific benefits of SF for some at-risk groups, it also helps to construct a more egalitarian and cohesive society that reinforces loyalty to place and an established basis for territorial development (Pallarès-Barberà et al. 2004).

Many SF initiatives, either due to the ideology of their sponsors or the advantages of CAP policies (Katsarova 2013), choose to focus on ecological, organic or biodynamic agriculture (Lockwood 1999), or at least to ensure that integrated or conventional production minimizes the use of chemical and transgenic products. At the same time, this sensitivity on the part of those who initiate or direct SF operations makes the farms an exponent, not only of social and economic development of a place but also of the reassessment of local culture and customs (Guirado et al. 2013a). They perceive the local cultural heritage as an active element that not only gives them singularity, with unique products in a very competitive market, but also allows them to adapt to their environment and plan for its exploitation based on local characteristics and natural cycles. In this sense, we must assess the return to particular varieties of local products, traditional farming techniques, and abandoned fields that can be recovered. Many traditional practices that were effective instruments for the conservation of the territory and landscape have been progressively lost, as in the case of today's large extensions of crops and cattle.

The SF projects also represent the emergence of a new farm community that opts for local production to support "proximity agriculture" that allows a direct connection with consumers. This new focus is supported among both traditional farmers and newcomers from urban areas (Monllor 2011). The intent is to reconfigure the current food system, working toward food autonomy by focusing on foods produced ethically, locally, and with social justice (Carbone and Senni 2010). Parallel to the emergence of this new farm paradigm, there are the new patterns of consumption in the postindustrial nations. In these countries, society is increasingly sensitized and it has acquired food consumption habits that also focus on ecology, ethics, quality, proximity, healthfulness, and respect for the environment (Verbeke 2005). In recent years, the consumption of ecological agricultural products in Spain has increased significantly: a $7 \%$ rise in 2011 , achieving a market share of about $2 \%$. The amount of agricultural land dedicated to ecological farming is constantly increasing in Spain ${ }^{8)}$

The products of SF operations in Catalonia (Table 1) are perfectly suited to these consumer habits, meeting the needs of these emerging market segments as they continue to grow in importance. Consumption patterns combining quality and ethical considerations offer a clear commercial opportunity for business and economic viability. The products are sold on-site at the farm, through cooperatives or consumer groups and specialized establishments as "proximity agriculture", shortening the commercial cycle and guaranteeing total traceability of product origin, which adds even more value.

8) Data source: Ministerio de Agricultura, Alimentación y Medio Ambiente, Anuario 2011. 
Main characteristics of Catalan Social Farming experiences in a SWOT analysis

\section{[STRENGTHS] \\ AGRICULTURE}

- Strategic sector in current economic crisis

- Multifunctionality and crop diversification

- Local food movement ("farm-to-table") and improved profile of agricultural practices

- Implementation of sustainable agriculture standards and social values

\section{TERRITORY}

- Contribution to local development and social fabric

- Creation of services to take care of people

- New relationships between producers, consumers

and society in general

SOCIAL INNOVATION AND ENTREPRE-

NEURSHIP

- Return-on-investment for public funding

- Initiatives with a civic origin

- Strengthening of public-private cooperation

\section{BENEFICIARIES}

- Special-needs groups gain appropriate employment opportunities

- Individuals at risk of social exclusion gain support

- User groups (producers, consumers and society in general)

\section{[WEAKNESSES]}

MANAGEMENTIORGANIZATION

- Dependence on public funding

- Low productivity outcomes

- Delay of non-payment of subsidies

\section{CONTEXT}

- Emerging sector with a limited track record

- Practices are not well codified

- Networks are not well structured

\section{BENEFICIARIES}

- Under representation of certain groups

- Difficulties in meeting the special needs of certain groups/individuals

\section{[OPPORTUNITIES]}

\section{CURRENT CONTEXT}

- Socioeconomic scenario demands innovation and projects with social merits

- Changes in consumption patterns (e.g. interest in production with ethics and justice, Fair Trade) and eating habits (preference for organic products)

\section{EMPLOYMENT AND SOCIAL EQUALITY}

- New employment opportunities in agriculture and related sectors

- Need to create initiatives that provide employment and reduce the impact of economic crisis

\section{SOCIETY}

- Alternative financing pathways

- Use of new technologies

- Broad network of Third Sector initiatives in Catalonia

\section{INSTITUTIONS}

Programs that encourage a social economy Assistance for entrepreneurship and innovation

\section{[THREATS]}

CONTEXT

- Uncertainty and hesitance about entrepreneurship

- Lack of social awareness and recognition - Neoliberal model of business objectives vs economics based on ethics and solidarity

\section{SOCIAL FARMING SITUATION}

Limited appreciation of the social contributions of SF (e.g., at-risk groups)

Limited awareness of SF in Catalonia, compared to elsewhere in the EU

POLITICS/INSTITUTIONS

- Cutbacks in social welfare funding

- Socialization and privatization of health care and social services

- Excessive bureaucracy and administrative limitations

- Lack of a regulatory framework and a lack of political will

Source: Own elaboration from RecerCaixa project 
More specifically, we can consider the various groups of activities that rely on SF in Catalonia, and they may contribute to local and regional development. Among others, these include the following:

- $\quad$ Greenhouses and garden centres have been, and remain, among the most common activities used to provide jobs for those with physical and mental disabilities. In some cases, these workers' families have established foundations to create cooperatives or not-for-profit businesses. They are normally located in rural areas close to cities.

- Vegetable and flower production, at small- and mid-scale, is among the activities that employ the greatest diversity of at-risk groups. In Catalonia, local governments and the Caritas Foundation of the Catholic Church have provided the most land for use by socially marginalized groups (unemployed, the elderly, ex-drug addicts, etc.). The production is often for local sale or for consumption by the group working the land. There are also gardens located at prisons near Martorell and in the City of Mallorca.

- $\quad$ Ecological production of eggs and small animals (rabbits, chickens, partridges, etc.) is an emerging activity in response to the growing demand for these affordable foods in a period of economic crisis. These installations are mid-sized but very modern and equipped with technology.

- $\quad$ Farms with sheep and goats, both for meat and milk products, are difficult to establish. They require special training in pasturing, sanitation, and production techniques, along with a large investment in land, animals, and workers. Most of these initiatives are located in rural mountain areas or far from the cities.

- $\quad$ Beef and dairy cattle are among the most adaptable to ecological standards. In the SF context, these are normally mid-sized operations that hire at-risk individuals. However, in Catalonia there is an example of a large dairy products company, "La Fageda" (Xarxa CX AgroSocial 2011), with a 5\% market share for yoghurt sales. The company's operations range from caring for the dairy cows to selling the final products. Its success comes from its niche in the ethical products market, its cooperative business structure, being part of a network, and the public SEC benefits available to it.

- $\quad$ The cultivation of mid-sized vineyards and olive groves is expanding because of the diversity of jobs that can be learned relatively easily by at-risk groups. Added value is achieved by making wine and oil, normally produced ecologically and marketable as a high-quality product. L'Olivera ${ }^{9}$, described in the next section, exemplifies this type of operation.

- $\quad$ Food production industries, restaurants and catering businesses that employ at-risk groups require increased organization. For this reason, SF involves foundations, cooperatives and businesses, and there is an important commitment to providing advance training for these workers.

- $\quad$ Rural tourism can be readily combined with agrarian projects, and can have very diverse functions. It provides jobs for individuals with disabilities but also to those at risk

9) Information obtained from the in-depth interview and the cooperative's website: http:// www.olivera.org [last update 01-04-2014] 
of social exclusion. This is also the modality that best incorporates environmental education.

Finally, it is important to discuss the legal aspects of the entities involved in SF, which vary by country. Spain passed its legislation on hiring individuals with a disability, LISMI ${ }^{10)}$, in 1982 . In Catalonia, the alternative option is the SEC ${ }^{11)}$, described in the methodology section, and inclusive or sheltered work environments, businesses that have more flexibility in the type of at-risk groups from which they contract employees.

A Catalan Social Farming experience: L'Olivera cooperative as a case study. L'Olivera is a social integration cooperative established in 1978 in Vallbona de les Monges, a small village in Catalonia's Urgell County. It was an initiative by a young urban group that decided to move to a rural area with a deep structural crisis. They were motivated by the possibility of building an alternative lifestyle model, and arrived in the village at a time when the local population was abandoning their fields and closing up their houses to move to the city. This project was closely linked to the land and built around two main pillars: agrarian production and living in the community, with the objective of working alongside people with disabilities.

The origin of this project was an effort to promote endogenous local development based on the agrarian sector, attempting innovative production and supporting cooperative work with at-risk individuals. They worked cooperatively, rather than each person for himself or herself. After various attempts, in 1985 they decided to create a bodega and begin wine production, from the vine to the sale to consumers. In 1986, this became a Special Job Centre, under the provisions of Spain's LISMI.

In the early 1990s, annual wine production reached 14,000 bottles, and it has since increased to 100,000 . At the same time, the group began to cultivate olive trees - recovering abandoned groves - and to produce ecological oil. The increased production has required them to expand their facilities, including an olive press on site and space for the machinery to bottle and store their products. This has resulted in a greater commercial presence, increasing the sales volume and export quotas. At present, the cooperative has 50 employees, of whom $50 \%$ have some type of psychological disability or mental disorder. Their decision to work in the social and collaborative economy has led to an organizational model that fully integrates all of the employees, giving individuals with disabilities the opportunity to be full members of the cooperative, if they so choose. This has led to greater confidence in the project and more involvement by all of the participating groups. Their work helps them feel valued by the cooperative, integrated into the community, and able to live a more normal life.

In terms of local development, the work done at l'Olivera is multifunctional because it is not only the production of wine and oil and the integration of people with disabilities into the organization, but it also includes new activities in the realm of social economy. These activities establish socially valuable links with other economic initiatives, such as the creation of

10) Article 49 of the 1976 Spanish Constitution (1976) requires that policies be established to provide for, treat, rehabilitate and integrate into society those with physical, sensory and psychic disabilities. The 1982 law for social integration of people with disabilities (LISMI, Ley 13/1982, 7 April), established norms by which public and private businesses with more than 50 employees, of which at least $2 \%$ have a disability, receive fiscal incentives.

11) Special Employment Centers were created by the Department of Labor and Department of Social Welfare of the Generalitat de Catalunya in 2009. There are specific agreements between the Administration and the various types of businesses, cooperatives or foundations, which provide economic benefits in exchange for hiring at-risk individuals and providing care and treatment services. 
networks of joint commercialization. Those efforts have been complemented with wine tourism activities and visits to the bodega, which bring visitors to the area who combine their stay in the village with visits to the Cistercian convent of the same name (Vallbona de les Monges means Good Valley of the Nuns).

In this sense, l'Olivera is among the SF successes in Catalonia, incorporating at-risk individuals into a successful rural development project. It is economically viable, socially just and environmentally sustainable, demonstrating that it is possible to create regional development strategies that combine social economy and agroecology promotion. In addition, SF is a growing trend in Catalonia, with a symbiosis between social action and agriculture, despite the current economic crisis. The 15 members of the CX AgroSocial network (2011) provide the basic structure for rural development in Catalonia, but there are others who could choose to join.

\section{Conclusions}

It is evident that activities related to SF have increased over the past 25 years in Europe; in some countries the number of farms, businesses or cooperatives has multiplied by a factor of 20 or more. The origins of these entities can be categorized into four main types, which in one way or another converge when SF activity becomes standardized: first, public or religious organizations have adapted SF to therapies used in health care centres, to redirect young people who have not done well in school, or to support the reintegration of recovering drug addicts or those who have been incarcerated; second, associations and foundations created by families to provide work and better living conditions for individuals with physical or mental disability; third, private initiatives through cooperatives or businesses, often not-for-profit, that provide therapeutic services and attempt to combine the incorporation of at-risk groups into the working world with income generating activities; and finally, the legislation in each country related to at-risk groups and also specific laws permitting SF entities that guarantee funding in exchange for particular provisions.

At a mature phase of SF implementation, networks emerge to bring together and coordinate the efforts of diverse agents and businesses. Local governments and later national governments as well, are becoming aware of the importance of this new activity to the development of rural areas, with the double objective of creating needed services and generating additional income for the served population. This new social function for agriculture is strengthened by the ecological orientation of its production methods and by its respect for the land and the environment. The current priority attached to food autonomy and local agriculture strengthens SF by attracting consumers who prefer to purchase these healthier products from producers who share their ethics.

Recently, due to the efforts of various networks of scientists, the EU has included SF in the funding objectives for rural development (2014-2020). This activity therefore becomes one of the elements to be considered in proposing policies for regional development, especially when these are not isolated activities but rather incorporated into various types of networks.

Finally, we could conclude that there are a series of social and economic benefits for rural areas, which could increase as SF becomes more widespread: (a) the creation of employment opportunities for current and future at-risk groups; (b) diversification in farm products; (c) new agrarian and rural initiatives, beyond the tourism sector, that strengthen multifunctionality and create added value; (d) consolidation of sustainable ecological agriculture and support for both quality and proximity in systems of product distribution; (e) increased social services for at-risk 
individuals in rural contexts, where resources are scarce and it is difficult to meet their needs; (f) the arrival of new families in small villages, attracted by new employment opportunities related to SF and by services adapted to their needs; $(\mathrm{g})$ expansion of the types of entities and initiatives that combine agrarian and other, more urban, activities that require a high-quality natural environment; (i) the empowerment of at-risk groups; and, among others, (j) the possibilities for social and employment integration that can result in a decreased probability of recurrence (e.g., former inmates), and greater self-confidence for members of these groups.

In the development arena, SF offers a clear example of economic and social innovation, closely related to collective action and to active, participative and ongoing interaction between individuals, agents and territorial resources. These facilitate the creation of networks of collaboration and cooperation at the local level that promote social cohesion and help to stabilize the population of a territory, while increasing the feeling of belonging to a community and encouraging cooperation.

\section{Acknowledgements}

This article is based on the project "Social Farming in local development as an occupation for groups at risk of marginalization" (RecerCaixa 2011 ACUP023), 1-01-2012/31-12-2013, carried out by Anna Badia, Maria Barrachina, Carles Guirado, Antoni F. Tulla (Dir), Natàlia Valldeperas, Ana Vera (Geography Department at UAB) and Camille Evard, Imma Pallarès and Marta Rancaño (CEDRICAT Foundation).

\section{References}

Own elaboration from Social Farming in local development as an occupation for groups at risk of marginalization (RecerCaixa 2011 ACUP023).

ANUARI DEL TERCER SECTOR SOCIAL A CATALUNYA (2009), Barcelona: Taula d'entitats i Observatori del tercer sector de Catalunya, http://www.anuaritercersectorsocial.cat, [last update 01-04-2014].

ARMESTO X. (2005), Notas teóricas en torno al concepto de postproductivismo agrario, Investigaciones Geográficas 36, 137-156.

BARRACHINA M., TULLA A. F. (2010), Els canvas socioambientals al Pirineu català: La Vall Fosca com a escenari representatiu de les mutacions en les economies tradicionals de muntanya, Documents d'Anàlisi Geogràfica 56 (3), 557-572.

BERENGUER E. (2013), El paper de la dona en l'Agricultura Social a Catalunya, Master Thesis of METiP (Supervisor: A. F. Tulla), Geography Department, Universitat Autònoma de Barcelona.

BOCK B. B. (2004), Fitting in and multi-tasking: Dutch farm women's strategies in rural entrepreneurship, Sociologia Ruralis 44 (3), 245-260.

CARBONE A., SENNI S. (2010), Consumers' Attitude Toward Ethical Food: Evidence from Social Farming in Italy, in Dessin J., Bock B. B. (eds.), The Economics of Green Care in Agriculture, Loughborough University Press, Loughborough, 76-97.

CLOKE P. (2006), Conceptualizing rurality, in Cloke P., Marsden T., Mooney P. (eds.), Handbook of Rural Studies, Sage Publications, London, 18-28.

CLOUT H. (1972), Rural Geography: an introductory survey, Pergamon, Oxford.

COST Action 866 (2006-2010), Green care in Agriculture (EU project: Food and Agriculture) http://www.umb.no/greencare/ [last update 01-04-2014].

BELL D. (1999, 1973), The coming of post-industrial society, Basic Books, New York.

DI IACOVO F. (2003), New trends in the relationship between farmers and local 
communities in Tuscany, in Van Huylenbroeck G., Durand G. (eds.), Multifunctional Agriculture: a new paradigm for European agriculture and rural development, Asgate, Aldershot, 101-128.

DI IACOVO F. (2010), L'agricoltura sociale: pratiche e paradigm nello scenario comunitario, XLVII Convegno di Studi de la Società Italiana di Economia Agraria "L'agricoltura oltre le crisi" 22-25 settembre de 2010, Università degli Studi del Molise, Campobasso.

DI IACOVO F. (2011), I buoni frutti dell'agricoltura civica, in Durastanti F., Galasso A., Orefice G., Paolini S., Rizzuto M. (eds.), I Buoni Frutti Viaggio nell'Italia della nuova agricultura civica, ética e responsabile, Agra Editrice, Roma.

DI IACOVO F., O'CONNOR D. (eds.) (2009), Supporting Policies for Social Farming in Europe. Progressing Multifunctionality in Responsive Rural Areas, ARISA, Firenze.

ESPING G. (1995), II welfare state senza il lavoro. L'ascesa del familismo nelle politiche sociali dell'Europa continentale, Stato e mercato 45, 347-380.

FOSTER J. E., SEN A. (1997), On Economic Inequality, Oxford University Press, New Delhi.

GUIRADO C., BADIA A., TULLA A. F., VERA A. (2013a), Agricultura Social: Economía social y dinamización agroecológica como estrategia de Desarrollo Local. El caso de l'Olivera Cooperativa (Urgell, Cataluña), Alacant, Comunicación al IX Coloquio Nacional de Desarrollo Local de la AGE.

GUIRADO C., BADIA A., TULLA A. F., VERA A., VALLDEPERAS N. (2013b), L'Agricultura Social. Aproximació teòrica i dimensión en el context europeu, in BIBLIO 3W, Revista bibliográfica de Geografía y Ciencias Sociales, Electronic paper XVIII (1046), 25 de Octubre de 2013.

HAUGAN L. R., NYLAND E., FJELDAVLI T., MEISTAD B., BRAASTAD O. (2006), Green Care in Norway; farms as a resource for the educational, health and social sector, in Hassink, J., van Dijk, M. (eds.), Farming for health. Green-care farming across Europe and the USA, Springer, Dordrecht, 109-126.

HINE R., PEACOCK J., PRETTY J. (2008), Care farming in the UK: contexts, benefits and links with therapeutic communities, International Journal Therapeutic Communities 29, 245 -260 .

IDESCAT (2013), Barcelona, Institut d'Estadística de Catalunya, http://www.idescat.cat/ dequavi/Dequavi?TC=444\&V0=2\&V1=6 [last update 01-04-2014].

ISTAT (2006), Le cooperative sociali in Italia, Istituto Nazionale di Statistica, Roma, http://www.istat.it/ [last update 01-04-2014].

KATSAROVA I. (2013), Common Agricultural Policy after 2013. What will change, Library of the European Parliament - Library Briefing [Retrieved 11 August 2013] http:// www.europarl.europa.eu/RegData/bibliotheque/briefing/2012/120236/LDM_BRI(2012)

120236_REV1_EN.pdf [last update 01-04-2014].

LIPTON M. (1977), Why poor people stay poor: a study of urban bias in world development, Temple Smith, London.

LOCKWOOD J. A. (1999), Agriculture and biodiversity: finding our place in this world, Agriculture and Human Values 16, 365-379.

MONLLOR N. (2011), Explorant la jove pagesia: camins, pràctiques $i$ actituds en el marc d'un nou paradigma agrosocial. Estudi comparatiu entre el sud-ouest de la provincia d'Ontario i les comarques gironines, Tesi de Doctorat, Universitat de Girona.

O'CONNOR D., LAI M., WATSON S. (2010), Overview of Social Farming and Rural Development Policy in Selected EU Member States, NRN Joint Thematic Initiative on Social Farming European Network for Rural Development, http://enrd.ec.europa.eu [last update 01-04 -2014].

PALLARÈS-BARBERÀ M, TULLA A. F., VERA A. (2004), Spatial loyalty and territorial embeddedness in the multi-sector clustering of the Berguedà region in Catalonia (Spain), Geoforum 35 (5), 635-649. 
PEARCE D. W. (1976), Environmental Economics, Longman Group Ltd., London.

PAHL R. (1966), The rural-urban continuum, Sociologia Ruralis 1 (6), 299-327.

RÉSEAU ASTRA (2009), http://www.res-astra.org/ [last update 01-04-2014].

RÉSEAU COCAGNE (2007), http://www.reseaucocagne.asso.fr/ [last update 01-042014].

SEMPERE J., TULLA A. F. (2008), El debat teòric sobre el periurbà i la concreció d'un planejament urbanístic en un entorn complex: el cas de Barcelona $i$ Tolosa, Documents d'Anàlisi Geogràfica 52, 125-144.

SEMPIK J., HINE R., WILCOX D. (eds.) (2010), Green Care: A Conceptual Framework. A Report of the Working Group on the Health Benefits of Green Care, COST 866, Green Care in Agriculture, Loughborough: Centre for Child and Family Research, Loughborough University, Loughborough.

SoFar (2005, 2008), Social Services in Multifunctional Farms ('Social Farming'), http:// sofar.unipi.it/ [last update 01-04-2014].

TÁLÂNGǍ C., ZAMFIR D., STOICA I. V. (2011), Planification du territoire dans le contexte européen et national, in lanoş I., Popa N., Cercleux A. L. (eds.), Éléments de planification territoriale et développement régional, Editura Universitară, Bucarest, 11-27.

TULLA A. F., PALLARĖS-BARBERÀ M., VERA,A. (2009), Naturbanization and local development in the mountain areas of the Catalan Pyrenees, in Prados M. J. (ed.), Naturbanization. New identities and processes for rural - natural areas, London, Taylor \& Francis Group, London, 75-92.

UGT (2012), Les persones amb discapacitat I el mercat de treball a Catalunya, Informe 2012. Secretaria d'Igualtat I Polítiques Socials, Barcelona, UGT de Catalunya.

VAN DER PLOEG J. D. (2006), Agricultural production in crisis, in Cloke P., Marsden T., Mooney P. (eds.), Handbook of Rural Studies, , Sage Publications, London, 258-277.

VERBEKE W. (2005), Agriculture and the food industry in the information age, European Review of Agricultural Economics 32 (3), 347-368. Cambridge.

WALLERSTEIN I. (1979), The Capitalist world-economy, Cambridge University Press,

WILLEMS J. (2013), Opinion of the European Economic and Social Committee on 'Social farming: green care and social and health policies, Official Journal of the European Union (2013/C 44/07).

WOODS M. (2005), Rural Geography: processes, responses and experiences in rural restructuring, Sage Publications, London.

Xarxa CX AgroSocial (2011), http://www.fundaciocatalunya-lapedrera.com/ca/content/ xarxa-agrosocial [last update 01-04-2014].

ZAMFIR D., TǍLÂNGĂ C., STOICA I. V. (2009), Romanian small towns searching for their identity, Journal of Urban and Regional Analysis I (1), 41-53.

Initial submission: 31.10 .2013

Revised submission: 28.03.2014

Final acceptance: 10.06.2014

Correspondence: Department of Geography, Universitat Autònoma de Barcelona, Catalonia, Plaça Cívica, Campus de la UAB, 08193 Sardañola del Vallés, Barcelona, Spain

E-mail: antoni.tulla@uab.cat 
